\title{
Phytochemical Screening and Content Determination of Differ- ent Species of Genus Caesalpinia belonging to Different Origin with Antidiabetic Activity
}

\author{
Amna Parveen ${ }^{1,2,3, *}$, Zahra ${ }^{4}$, Muhammad Qudratullah Farooqi ${ }^{5}$, Whang Wan Kyunn², Muhammad Arshad ${ }^{4}$
}

\section{Amna Parveen ${ }^{1,2,3, *}$, Zahra ${ }^{4}$, Muhammad Qudratullah Farooqi ${ }^{5}$, Whang Wan Kyunn ${ }^{2}$, Muhammad Arshad ${ }^{4}$}

'College of Pharmacy, Gachon University, No. 191, Hambakmoero, Yeonsu-gu, Incheon 406-799, REPUBLIC OF KOREA. ${ }^{2}$ Pharmaceutical Resources Botany Laboratory, Department of Pharmacognosy, College of Pharmacy, Chung-Ang University, Room No:416, bldg.: 102, 221, Heukseok-dong, Dongjak gu, Seoul 156-756, REPUBLIC OF KOREA. ${ }^{3}$ Department of Pharmacognosy, College of Pharmacy, Government College University Faisalabad, Faisalabad, PAKISTAN.

${ }^{4}$ Institute of Environmental Sciences and Engineering, School of Civil and Environmental Engineering, National University of Sciences and Technology, Sector H-12, Islamabad 44000, PAKISTAN.

${ }^{5}$ Department of Applied Plant Sciences, College of Agriculture and Life Sciences, Kangwon National University, Chuncheon 24341, REPUBLIC OF KOREA.

\section{Correspondence}

Amna Parveen, College of Pharmacy, Gachon University, REPUBLIC OF KOREA.

Phone no: +82-32-820-4932

E-mail: amnaparvin@gmail.com

History

- Submission Date: 15-05-2017;

- Review completed: 08-06-2017;

- Accepted Date: 22-08-2017

DOI : 10.5530/pj.2017.6.117

Article Available online

http://www.phcogj.com/v9/i6

\section{Copyright}

(C) 2017 Phcog.Net. This is an openaccess article distributed under the terms of the Creative Commons Attribution 4.0

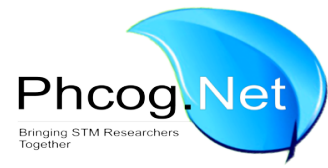

\begin{abstract}
Aim: The main aim of the study is to investigate the phytochemical screening of $C$. decapetala along with the content determination of different species of genus Caesalpinia with respect to their antidiabetic activity and identification of most bioactive species belonging to different origins. Methods: To achieve our goal different species of genus Caesalpinia collected from China and Pakistan were subjected to open column chromatography, High Pressure Liquid Chromatography (HPLC), antioxidant, and antidiabetic assays for evaluation. Results: From $\eta-\mathrm{BuOH}$ fraction of $C$. decapetala extract, eight compounds were isolated using open column chromatography and identified as apigenin-7-rhamnoside (1), 4-O-methylepisappanol (2), caesalpinol (3), daucosterol (4), astragalin (5), kaempferol (6), quercitrin (7), and naringin (8) using Nuclear Magnetic Resonance (NMR) spectroscopy. HPLC analysis of different species of genus Caesalpinia showed that the most active antidiabetic compound 'quercitrin' was present more in C. pulcherrima followed by decreasing order in C. sappan, C.decapetala, and $C$. bonduc. Conclusion: The results indicated that quercitrin is the most bioactive content and $C$. pulcherrima is most bioactive specie of China origin from genus Caesalpinia.
\end{abstract}

Key words: Flavonoids, Antioxidants, Antidiabetic, HPLC fingerprint, Caesalpinia, Phytochemical content.

\section{INTRODUCTION}

Chronic hyperglycemia, a major characteristic of diabetes mellitus (DM), is responsible for the deregulation of energy metabolism. Consequently, there is either the failure of production or response to hormonal insulin. Continued hyperglycemia due to DM causes varieties of dysfunctions and complications including renal disease, peripheral neuropathy, cardiovascular diseases, myocardial infarction, and non-healing foot ulcer. ${ }^{1}$ There is growing evidence that reactive oxygen species (ROS) is the major cause of stimulating DM mechanisms ${ }^{2,3}$ and responsible for the initiation of lipid peroxidation, enzyme deactivation, alteration in the collagen structure, and function. ${ }^{3,4}$ In other words, we can say ROS have long term effects on the progression of diabetes. Therefore, by using the antioxidant, the oxidative stress caused by these ROS can be relieved, thus reducing the risk of damage to the pancreas. Carbohydrate hydrolyzing enzymes including a-glucosidase may be utilized for blocking the breakdown of starch and disaccharide into glucose and made glucose less available for absorption into the blood and ultimately sugar elevated level into the blood can be controlled. ${ }^{5}$ Protein tyrosine phosphatase $1 \mathrm{~B}$ (PTP1B) is considered as the main regulator of body stored body fat, insulin resistance, and energy balance. Insulin controls various functions at the level of gene transcription, protein translation, and enzyme activity. PTP1B is the negative regulator of insulin signaling mechanism. It improves the insulin sensitivity in obese patients. Deletion of overexpression of PTP1B could be an effective and potential therapy for ameliorating diabetes and obesity. ${ }^{6}$ Therefore, by considering these causing factors, diabetes can be controlled and ameliorated. Many types of medicinal plants and their extracts have been reported with significant antidiabetic activity due to the presence of phytochemicals which are responsible for providing protection from disease prevalence. C. decapetala (CD), known as Roth, is a pantropical genus belonging to family Fabaceae around 120-1250 species of tree, shrubs and lignans. Traditionally, several species belonging to genus Caesalpinia have been known to possess properties as anti-inflammatory, antidiabetic, hepatotoxicity, wound healing, and fever. $^{7}$ Recently a study was conducted which proved the traditional use of extract of $C$. 
decapetala against diabetes ${ }^{8}$, but no study was reported yet which identify the responsible phytochemicals playing role in diabetes prevention. Therefore, the current study was designed to investigate the phytochemical screening and content determination of different species of genus Caesalpinia belonging to different origins with respect to their antidiabetic activity and the identification of most bioactive specie.

\section{MATERIAL AND METHODS}

\section{Chemicals}

Acetonitrile, Methanol (MeOH), Water, Formic acid HPLC-grade (Daejung, chemical, Korea), Hexane (Hx), Ethyl acetate(EA), Dichloromethane (DCM), and $n$-Butanol $(n-\mathrm{BuOH})$ (Daejung, chemical, Korea), MeOH-d4 (Sigma-Aldrich, USA), Phosphoric acid HPLC-grade (Daejung, chemical, Korea), Dimethylsulfoxide (DMSO) (Sigma-Aldrich, USA), ascorbic acid (AA), dinitrosalicylic acid, trolox, Acarbose, pyragallol, sodium chloride, sodium phosphate mono basic, sodium phosphate dibasic, xanthine oxidase, nitro blue tetrazolium (NBT), ethylene diamine tetra acetic acid (EDTA), 2,2'-azino-bis(3-ethylbenzthiazoline-6-sulfonic acid) (ABTS), a-glucosidase, $\rho$-nitrophenylphosphate ( $\rho N P P)$, DPPH (2,2-diphenyl-1-picrylhydrazyl), 4-nitrophenyl $\beta$-Dglucopyranoside ( $\rho$-npg), ursolic acid, protein tyrosinase, and phosphatase 1B (Sigma-Aldrich, USA).

\section{Plant collection}

During the month of July 2013, C. decapetala leaves were collected for isolation of major compounds from Dir, Pakistan and identified by Professor Whang Wan Kyunn. Collections of samples for HPLC analysis were done from South China botanical garden, Guangzhou, Guangdong Province, China, GC University Lahore, and local market from Punjab, Pakistan. All plants specimens were submitted to the laboratory of pharmaceutical resources of the college of Pharmacy, Chung-Ang University, Seoul, South Korea.

\section{Extraction and isolation of major components}

Air dried $650 \mathrm{~g}$ of powdered leaves were extracted with $100 \% \mathrm{MeOH}$ and dried under vacuum in a rotary evaporator, consequently, about $41 \mathrm{~g}$ dry extract was received. The methanolic extract was further partitioned with $n$-hexane (15 g), DCM (12 g), EA (10 g), n-BuOH) (6 g) and water $(10 \mathrm{~g})$ and dried in a rotary evaporator. To analyze the antioxidant property, DPPH assay was performed. Furthermore, thin layer chromatography (TLC) using the mobile phase (EA: GAA: FA: W; 100: 11: 11: 26) for the selection of fraction for further isolation. $n$ - $\mathrm{BuOH}$ fraction was selected for further isolation. For isolation of compounds, $n-\mathrm{BuOH}$ extract ( $5 \mathrm{~g}$ ) was chromatographed on the Sephadex column and eluted with $30 \%$ to $80 \% \mathrm{MeOH}$ which provided 1-7 fractions based on TLC profile. Fractions C. decapetala butanol (CDB) 3, 4, 5, and 7 were further subjected to repeated Sephadex column and ODS column and eluted with $\mathrm{MeOH}$-water (20 to $100 \%$ ) gradient elution. Fraction CDB 3 was further eluted on ODS column using $40-60 \% \mathrm{MeOH}$ and gave further 3 subfractions. Finally, CDB 3-2-2 contained compound 1 (23 mg). Fraction CBD4 was further eluted with $40-60 \% \mathrm{MeOH}$ on Sephadex column and obtained 3 subfractions. From subfraction CBD4-1, further sub-sub-fractions gave CBD4-1-1 (Compound 2; $17 \mathrm{mg}$ ), CBD4-1-2 (compound 3; $11 \mathrm{mg}$ ), CBD4-1-3 (compound 4; $8 \mathrm{mg}$ ), and CBD4-1-4 (compound 8; $6 \mathrm{mg}$ ) by using ODS column with 40-60\% MeOH. From subfraction CBD5-4, compound 5 (40 mg) was obtained and from sub subfraction CDB5-4-2-8 compound 6 (15 mg) was obtained. Fraction CDB7 was eluted by $40-60 \% \mathrm{MeOH}$ on repeated Sephadex column which gave three subfractions. Subfraction CDB7-1 gave compound 7 (22 mg). For determination of structures of isolated compounds, samples were dissolved in $\mathrm{MeOH}-\mathrm{d}_{4}\left(\mathrm{CD}_{3} \mathrm{OD}\right)$ and then analyzed by ${ }^{1} \mathrm{H}-\mathrm{NMR}$ and ${ }^{13} \mathrm{C}-\mathrm{NMR}$.

\section{Development of fingerprint pattern by HPLC-UV of C. decapetala along with their quantitative and qualitative analysis}

The powdered leaves $(1 \mathrm{~g})$ of different samples of Caesalpinia species were sonicated in $100 \mathrm{~mL}$ of $\mathrm{MeOH}$ for $30 \mathrm{~min}$ for pattern investigation by HPLC-UV. RP-C18 kromas-il column $(250 \times 4.6,5 \mu \mathrm{m})$ was used with different gradient of mobile phase $(0.1 \% \mathrm{AA}$ in water (solvent $\mathrm{A}$ ) and $\mathrm{MeOH}$ (solvent B): 0 min, 95\% A; $10 \mathrm{~min}, 85 \% \mathrm{~A} ; 20 \mathrm{~min}, 70 \% \mathrm{~A}$; $30 \mathrm{~min}, 50 \% \mathrm{~A} ; 60 \mathrm{~min}, 95 \% \mathrm{~A}$ ). The column was equilibrated with $85 \%$ A for $10 \mathrm{~min}$ before next injection with the flow rate of $1 \mathrm{~mL} / \mathrm{min}$ at a wavelength of $330 \mathrm{~nm}$. The injected volume was $20 \mathrm{uL}$. The column temperature was kept at $25^{\circ} \mathrm{C}$. Peak analysis and identification were done with standard compounds and retention time using HPLC chromatography equipped with UV detector and further comparative analysis of isolated compounds was investigated.

\section{Antioxidant testing DPPH assay}

The DPPH activity of the isolated compounds and extract of Caesalpinia species were investigated using the method prescribed. ${ }^{9}$ In 96 well-plate $20 \mathrm{uL}$ of the sample with different dose of concentrations (1000, 500, 250, $125 \mathrm{ug} / \mathrm{mL}$ ) and isolated compounds (100, 75, 50, and $25 \mathrm{uM}), 180 \mathrm{uL}$ of the $0.1 \mathrm{mM}$ solution was added and incubated for $30 \mathrm{~min}$ at $37^{\circ} \mathrm{C}$. The absorbance was measured at $517 \mathrm{~nm}$. Each observation was performed in triplicate. Ascorbic acid (AA) and trolox were considered as positive controls. Furthermore, inhibition percentage was calculated.

\section{Measurement of superoxide anion radical scavenging activity}

Superoxide anion radical scavenging activity of the isolated compounds and extracts of Caesalpinia species were investigated using the method reported earlier. ${ }^{9} 160 \mathrm{uL}$ of reaction mixture containing hypoxanthine $0.6 \mathrm{mM}$, NBT $0.2 \mathrm{mM}$, and EDTA $1 \mathrm{Mm}$ were prepared in phosphate buffer solution $50 \mathrm{mM}$ containing $\mathrm{pH} 7.4$ was added in $20 \mathrm{uL}$ of test sample of different concentrations $(200,100,50$ and $25 \mu \mathrm{M})$ followed by incubation at $37^{\circ} \mathrm{C}$ for $8 \mathrm{~min}$ and measurement was done at $590 \mathrm{~nm}$. Allopurinol was used as positive control. All observations were measured in triplicate. Percentage inhibition was calculated.

\section{ABTS radical scavenging activity}

ABTS activity of the isolated compounds and extract of Caesalpinia species were investigated in accordance with the method prescribed. ${ }^{9}$ Stock solution containing $7.4 \mathrm{mM}$ of ABTS and $2.6 \mathrm{mM}$ of potassium per sulfate was prepared and kept for one day in the dark. Later, the dilution of the stock solution was done using the $\mathrm{MeOH}$ until the absorbance came within the range of $0.8-1.2$ at $732 \mathrm{~nm}$. To $50 \mathrm{uL}$ of sample solution of different doses $(250,125,100$ and $50 \mu \mathrm{M}), 950 \mu \mathrm{L}$ of ABTS was added. Absorbance was measured at $732 \mathrm{~nm}$ using a spectrophotometer. AA and trolox were used as positive control while $\mathrm{MeOH}$ was used as negative control. All observations were measured in triplicate. Percentage inhibition was calculated from the observations.

\section{a-glucosidase assay}

UV spectrophotometer was used to investigate the enzyme inhibition. The reaction mixture was prepared using $20 \mu \mathrm{L}$ of potassium phosphate buffer $100 \mathrm{mM}$ (Ph 6.8) and $20 \mu \mathrm{L}$ of $\rho$-npg $2.5 \mathrm{mM}$. Add $40 \mu \mathrm{L}$ of the reaction mixture to $20 \mu \mathrm{L}$ of sample with different concentrations $(100 \mu \mathrm{M}, 50 \mu \mathrm{M}, 25 \mu \mathrm{M}$ and $12.5 \mu \mathrm{M})$ in 96 well-plate. After that $20 \mu \mathrm{L}$ $0.2 \mathrm{U} / \mathrm{mL}$ a-glucosidase was added and incubated for $15 \mathrm{~min}$ at $37^{\circ} \mathrm{C}$. To terminate the reaction, then $80 \mu \mathrm{L}$ of sodium carbonate $0.2 \mathrm{mM}$ was 
added and absorbance was measured at $405 \mathrm{~nm}$. Acarbose $(100 \mu \mathrm{M}$, $50 \mu \mathrm{M}, 25 \mu \mathrm{M}$ and $12.5 \mu \mathrm{M}$ ) was used as a positive standard. The buffer solution was used as a control. The inhibition percentage was calculated with following formula $\left[\left(A_{c}-A_{s}\right) / A_{c}\right] \times 100 \%$. $A_{c}$ represents the absorbance of control and $A_{s}$ represents the absorbance of sample. ${ }^{10}$

\section{PTP1B inhibitory assay}

To investigate the PTP1B inhibitory activity, to each 96 well-plate $50 \mu \mathrm{L}$ of reaction mixture containing $\mathrm{PTP} 1 \mathrm{~B}$ in a buffer composite of citrate buffer 50mM with $\mathrm{pH} 6, \mathrm{NaCl} 0.1 \mathrm{mM}$, EDTA $1 \mathrm{mM}$, and DTT $1 \mathrm{mM}$ with or without samples of different concentrations $(100 \mu \mathrm{M}, 50 \mu \mathrm{M}$, $25 \mu \mathrm{M}$ and $12.5 \mu \mathrm{M}$ ) and pre-incubation was done for $10 \mathrm{~min}$ at $37^{\circ} \mathrm{C}$. After that, $50 \mu \mathrm{L}$ was added and again incubated for $30 \mathrm{~min}$ at $37^{\circ} \mathrm{C}$. After that $10 \mu \mathrm{L}$ of $10 \mathrm{M} \mathrm{NaOH}$ was added to stop the reaction. The absorbance was measured at $405 \mathrm{~nm}$. Ursolic acid was used as positive control. The inhibition percentage was calculated with following formula $\left[\left(A_{c}-A_{s}\right) /\right.$ $\left.A_{c}\right] \times 100 \%$. $A_{c}$ represents the absorbance of control and $A_{s}$ represents the absorbance of the sample. ${ }^{10}$

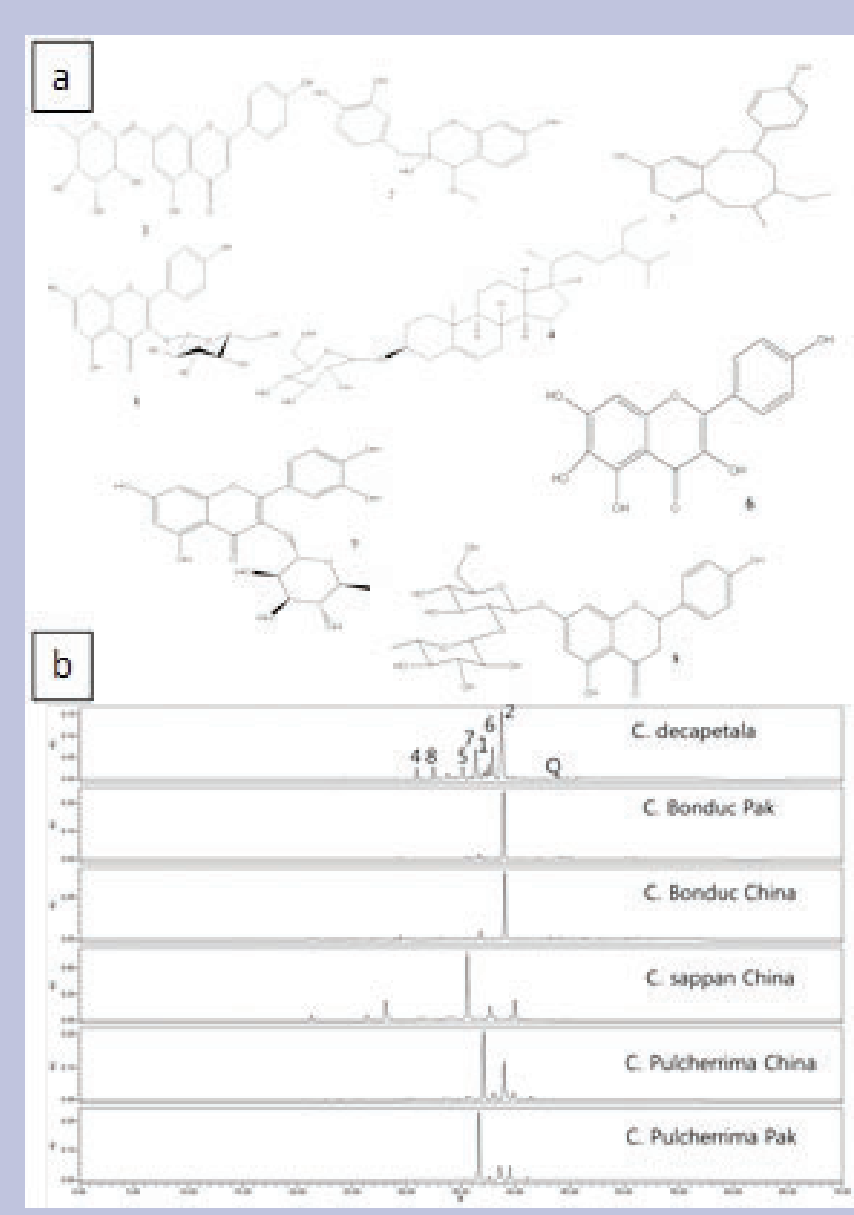

Figure 1: (a) Chemical structure of isolated compounds from $C$. decapetala. Apigenin-7-rhamnoside (1), 4-O-methyl episappanol (2), Caesalpinol (3), daucosterol (4), astragalin (5), 6-hydroxy kaemferol (6), quercitrin (7), and naringin (8). (b) Chromatogram of different species of genus Caesalpinia by HPLC-UV.

\section{Statistical analysis}

Data was presented as the mean \pm standard deviation (S.D). Data was analyzed using one-way ANOVA and level of significance were measured at $P<0.05$.

\section{RESULTS AND DISCUSSION}

\section{Phytochemical composition of $C$. decapetala leaf extract}

The results of DPPH activity showed that all partitions have significant activity. At the dose of $100 \mu \mathrm{g}$, ethyl acetate and $n-\mathrm{BuOH}$ showed the maximum inhibition percentage i.e., $78.56 \%$ and $88.50 \%$ respectively. Furthermore, TLC analysis showed the presence of more compounds so $\mathrm{n}-\mathrm{BuOH}$ were selected for further isolation. After repeated open column chromatography using Sephadex and ODS column, eight compounds isolated were further identified by NMR spectroscopy and their molecular structures are presented in Figure 1 (a). Among the isolated compounds, 5 are flavonoids and 1 is benzoxecin derivative, 1 is phytosterol like compound and last one is sappanol compound. The chemical structure of the isolated compounds was displayed in Figure 1 (a).

1: Apigenin-7-rhamnoside: ${ }^{1} \mathrm{H}-\mathrm{NMR}\left(600 \mathrm{MHz}, \mathrm{DMSO}-\mathrm{d}_{6}\right) \delta \mathrm{ppm}$. Ring A: 7.85 (d, 2H, J = 8.1, H-2' and H-6'); 6.88 (d, $2 \mathrm{H}, \mathrm{J}=8.1, \mathrm{H}-3^{\prime}$ and H-5'); Ring B; 6.78 (s, 1H, H-8); 6.73 (s, 1H, H-6); 6.32 (s, 1H, H-3); 5.11 (s, 1H, H-1"); 4.46 (s, H-2”); 3.34-3.71 (m, H-3",H-4”,H-5”); 1.18 (3H, H-6") ${ }^{13}$ C-NMR (150 MHz, DMSO-d $)$ א ppm: 182.3 (C-4, C=O), 164.68 (C-2), 162.94 (C-4"), 162.05 (C-4'), 161.43 (C-5), 157 (C-8), 128.8 (C-2',6'), 121.09 (C-1'), 116.41 (C-3' and C-5'), 105.79 (C-3), 18.50 (C-3”, $\left.\mathrm{C}-\mathrm{CH}_{3}\right)$.

2: 4-O-Methyl episappanol: ${ }^{1} \mathrm{H}-\mathrm{NMR}\left(600 \mathrm{MHz}, \mathrm{CD}_{3} \mathrm{OD}\right) \delta$ ppm: Ring A: $7.82\left(\mathrm{~d}, 1 \mathrm{H}, \mathrm{J}=7.44, \mathrm{H}-6^{\prime}\right) ; 6.85$ (d, $\left.1 \mathrm{H}, \mathrm{J}=7.44, \mathrm{H}-5^{\prime}\right) ; 6.75$ (s, $1 \mathrm{H}$, H-2); Ring B; 6.75 (s, 2H, H-7); 6.34 (s, 1H, H-6); 5.00 (d, 1H, J = 6.96, $\mathrm{H}-5) ; 3.13$ (s, 4- $\mathrm{OCH}_{3}$ ) and ${ }^{13} \mathrm{C}-\mathrm{NMR}$ according to literature. ${ }^{11}$

3: Caesalpinol: ${ }^{1} \mathrm{H}-\mathrm{NMR}\left(600 \mathrm{MHz}, \mathrm{CD}_{3} \mathrm{OD}\right) \delta \mathrm{ppm}: 7.03(\mathrm{dd}, 2 \mathrm{H}$, $\mathrm{J}=8.58,1.9 \mathrm{H}-6^{\prime}$ and $\left.2^{\prime}\right) ; 6.94(\mathrm{~d}, 1 \mathrm{H}, \mathrm{J}=2.2, \mathrm{H}-10) ; 6.82(\mathrm{dd}, 2 \mathrm{H}$, $\mathrm{J}=8.58,1.8, \mathrm{H}-5^{\prime}$ and $\left.\mathrm{H}-3^{\prime}\right) ; 6.66(\mathrm{~d}, 1 \mathrm{H}, \mathrm{J}=2.4, \mathrm{H}-8) ; 6.33(\mathrm{~s}, 1 \mathrm{H}, \mathrm{H}-7)$; 5.4 (d, $1 \mathrm{H}, \mathrm{J}=6.9, \mathrm{H}-2) ; 3.72$ (s, OCH3, H-14); 1.21 (s, H-6); $\delta 1.07$ (m, H-5) and ${ }^{13} \mathrm{C}$-NMR according to literature. ${ }^{12}$

4: Daucosterol: ${ }^{1} \mathrm{H}-\mathrm{NMR}$ (600 $\left.\mathrm{MHz}, \mathrm{CD}_{3} \mathrm{OD}\right) \delta \mathrm{ppm}: 5.33(\mathrm{~m}, 1 \mathrm{H}$, $\mathrm{H}-6)$; 3.59-3.66 (sugar moiety); 2.03 (m, 1H, H-12a), 2.01 (m, 1H, H-8); 0.93 (m, 1H, H-2a); 1.40 (m, 1H, H-11a); 1.28 (m, 1H, H-28); 1.18 (m, 1H, H-23); 1.17 (m, 1H, H-12b); 1.16 (m, 1H, H-17); 0.92 (m, 1H, $\mathrm{H}-9)$; 0.91 (m, 1H, H-21); 0.89 (m, 1H, H-26); 0.88 (m, 1H, H-24); 0.87 (m, 1H, H-29); $0.86(\mathrm{~m}, 1 \mathrm{H}, \mathrm{H}-27) ; 0.85(\mathrm{~m}, 1 \mathrm{H}, \mathrm{H}-18)$ and ${ }^{13} \mathrm{C}-\mathrm{NMR}$ according to literature. ${ }^{13}$

5: Astragalin: ${ }^{1} \mathrm{H}-\mathrm{NMR}\left(600 \mathrm{MHz}, \mathrm{CD}_{3} \mathrm{OD}\right) \delta \mathrm{ppm} .7 .93(\mathrm{~d}, 2 \mathrm{H}, \mathrm{J}=8.8$, H-2' and H-6'); 6.7 (d, 2H, J = 8.82, H-3' and H-5'); 6.79 (s, 1H, H-8); 6.78 (s, $1 \mathrm{H}, \mathrm{H}-6)$; 5.48 (d, J = 6.12, H-1"); 3.63-3.75 (m, 6H) and ${ }^{13} \mathrm{C}-$ NMR according to literature. ${ }^{14}$

6: 6-hydroxy kaempferol: ${ }^{1} \mathrm{H}-\mathrm{NMR}\left(600 \mathrm{MHz}, \mathrm{CD}_{3} \mathrm{OD}\right) \delta$ ppm: Ring A: $7.87\left(\mathrm{~d}, 2 \mathrm{H}, \mathrm{J}=8.6, \mathrm{H}-2^{\prime}\right.$ and $\left.\mathrm{H}-6^{\prime}\right)$; $6.94\left(\mathrm{~d}, 2 \mathrm{H}, \mathrm{J}=8.7, \mathrm{H}-3^{\prime}\right.$ and $\left.\mathrm{H}-5^{\prime}\right)$; Ring B; 6.60 (s, 1H, H-8). ${ }^{13}$ C-NMR (150 MHz, CD $\left.0 \mathrm{D}\right) \delta$ ppm: 182.3 (C-4, C=O), 165 (C-7), 161.4 (C-5), 162.05 (C-4'), 161.43 (C-5), 128.3 (C-2',6'), 122(C-1'), 115.63 (C-3' and C-5'), 102.5(C-3).

7: Quercitrin: ${ }^{1} \mathrm{H}-\mathrm{NMR}\left(600 \mathrm{MHz}, \mathrm{CD}_{3} \mathrm{OD}\right) \delta \mathrm{ppm}$ : Ring A: $7.9(\mathrm{~d}, 1 \mathrm{H}$, $\left.\mathrm{J}=7.9, \mathrm{H}-5^{\prime}\right) ; 7.4$ (dd, $\left.1 \mathrm{H}, \mathrm{J}=8.4,2.16, \mathrm{H}-6^{\prime}\right) ; 6.85$ (d, 1H, J=2.16, H-2') Ring B: 6.37 (d, 1H, J = 2.16, H-8); 6.18 (d, 1H, J=2.16, H-6); 5.31 (d, 1H, $\mathrm{H}-1$ "); 3.46-3.6(m), $\delta 1.2(\mathrm{~S}, 3 \mathrm{H})$ and ${ }^{13} \mathrm{C}-\mathrm{NMR}$ according to literature. ${ }^{15}$ 8: Naringin: ${ }^{1} 1 \mathrm{H}-\mathrm{NMR}\left(600 \mathrm{MHz}, \mathrm{CD}_{3} \mathrm{OD}\right) \delta \mathrm{ppm}$ : Ring A: $7.88(\mathrm{~d}, 2 \mathrm{H}$, $\left.\mathrm{J}=7.9, \mathrm{H}-2^{\prime}, 6^{\prime}\right) ; 6.94$ (d, 2H, J = 7.8, H-3', 5'); Ring B: 6.59 (s, 2H, H-6,8); 5.17 (Glc-1"); 5.13 (Rha-1"') and ${ }^{13} \mathrm{C}-\mathrm{NMR}$ according to literature. ${ }^{16}$ 
Parveen et al.: Content Determination of Different Species of Genus Caesalpinia

Table 1: Comparative analysis of isolated compounds in different species of genus Caesalpinia

\begin{tabular}{ccccccccc}
\hline \multicolumn{7}{c}{ Contents in dry leaves $(\mathrm{mg} / \mathrm{g})$ and retention time $(\mathrm{min})$ Means \pm SD } \\
\hline Sample Name & 1 & 2 & 4 & 5 & 6 & 7 & 8 & Quercetin (Q) \\
\hline Retention time (min) & 37.38 & 38.26 & 31.08 & 35.32 & 37.56 & 37.10 & 32.43 & 42.22 \\
C. decapetala Pak & $6.16 \pm 0.1$ & $9.65 \pm 0.0$ & $2.6 \pm 0.1$ & $1.41 \pm 0.1$ & $2.0 \pm 0.0$ & $8.07 \pm 0.2$ & $6.64 \pm 0.1$ & $0.03 \pm 0.05$ \\
C. bonduc Pak & $0.24 \pm 0.0$ & $14.0 \pm 0.3$ & $0.6 \pm 0.2$ & $0.37 \pm 0.0$ & $0.06 \pm 0.0$ & $2.27 \pm 0.0$ & $0.43 \pm 0.4$ & $0.33 \pm 0.01$ \\
C. bonduc China 1 & $0.08 \pm 0.0$ & $4.67 \pm 0.0$ & $0.5 \pm 0.0$ & $0.11 \pm 0.0$ & & $1.26 \pm 0.0$ & $0.86 \pm 0.0$ & $0.08 \pm 0.00$ \\
C. bonduc China 2 & $1.68 \pm 0.0$ & $28.2 \pm 0.0$ & $0.6 \pm 0.0$ & $0.10 \pm 0.0$ & $0.06 \pm 0.0$ & $3.75 \pm 0.0$ & $0.50 \pm 0.0$ & $0.07 \pm 0.003$ \\
C. bonduc China 3 & $4.85 \pm 0.0$ & $24.1 \pm 0.2$ & $5.4 \pm 0.0$ & $0.19 \pm 0.0$ & $0.20 \pm 0.0$ & $0.92 \pm 0.0$ & $2.16 \pm 0.0$ & $0.02 \pm 0.00$ \\
C. sappan China 1 & $33.5 \pm 0.0$ & $1.04 \pm 0.0$ & $2.59 \pm 0.0$ & $42.2 \pm 0.0$ & $0.36 \pm 0.0$ & $3.05 \pm 0.0$ & $6.17 \pm 0.0$ & $0.15 \pm 0.00$ \\
C. pulcherrima Pak 1 & $0.21 \pm 0.0$ & $1.05 \pm 0.0$ & $0.1 \pm 0.0$ & $1.62 \pm 0.0$ & & $0.28 \pm 0.0$ & $0.27 \pm 0.0$ & $0.03 \pm 0.00$ \\
C. pulcherrima Pak 2 & $0.22 \pm 0.0$ & $0.08 \pm 0.0$ & & $0.12 \pm 0.0$ & $0.03 \pm 0.0$ & $0.47 \pm 0.0$ & 0.00 \\
C. pulcherrima Pak 3 & $0.53 \pm 0.0$ & $0.52 \pm 0.0$ & & $0.08 \pm 0.0$ & $0.03 \pm 0.0$ & $1.09 \pm 0.0$ & 0.0 \\
C. pulcherrima Pak 4 & $4.15 \pm 0.0$ & $1.59 \pm 0.0$ & $0.38 \pm 0.0$ & $0.87 \pm 0.0$ & $0.10 \pm 0.0$ & $23.9 \pm 0.0$ & $2.33 \pm 0.0$ & $0.03 \pm 0.00$ \\
C. pulcherrima China 1 & $3.94 \pm 0.0$ & $17.9 \pm 0.0$ & $0.10 \pm 0.0$ & $0.14 \pm 0.0$ & $0.87 \pm 0.0$ & $46.3 \pm 0.0$ & $8.8 \pm 0.00$ & $0.15 \pm 0.00$ \\
C. pulcherrima China 2 & $2.07 \pm 0.0$ & $3.09 \pm 0.0$ & $0.25 \pm 0.0$ & $0.17 \pm 0.0$ & $2.00 \pm 0.0$ & $26.2 \pm 0.0$ & $0.10 \pm 0.0$ & $0.01 \pm 0.00$ \\
C. pulcherrima China 3 & $7.70 \pm 0.0$ & $15.9 \pm 0.0$ & $0.13 \pm 0.0$ & $0.21 \pm 0.0$ & $1.19 \pm 0.0$ & $69.1 \pm 0.0$ & $8.47 \pm 0.0$ & $0.14 \pm 0.00$ \\
\hline
\end{tabular}

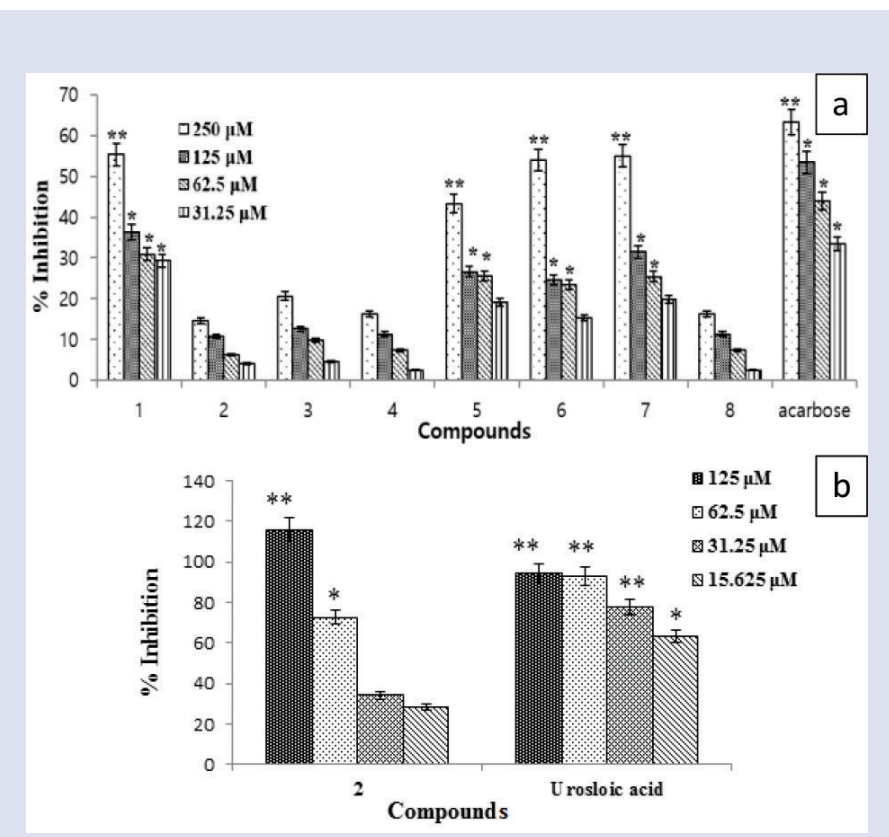

Figure 2: (a) Alpha-glucosidase activity of isolated compounds from C. decapetala. Values are expressed in mean \pm S.D $\left(^{* *} p\right.$ value $<0.02,{ }^{*}$ $<0.05, \mathrm{n}=3$ ). Apigenin-7-rhamnoside (1), 4-O-methyl episappanol (2), Caesalpinol (3), daucosterol (4), astragalin (5), 6-hydroxy kaempferol (6), quercitrin (7), naringin (8), and acarbose was used as standard. (b) PTP1B inhibition activity of isolated compounds from $C$. decapetala. Values are expressed in mean \pm S.D $\left({ }^{* *}\right.$ p value $\left.<0.01,{ }^{*}<0.05, n=3\right)$. 4-O-methyl episappanol (2), and Ursolic acid was used as standard.
Chromatogram of the standards along with the four-species collected from China and Pakistan eluted by HPLC-UV as represented in Figure 1 (b) and comparative analysis as mentioned in Table 1 . All compounds are present in C. decapetala which were identified by matching with their retention time in the extract. Furthermore, variations in the content analysis has been found in other species of Caesalpinia. The data showed that highest peak of compound 2 (4-O-methyl episappanol) is found

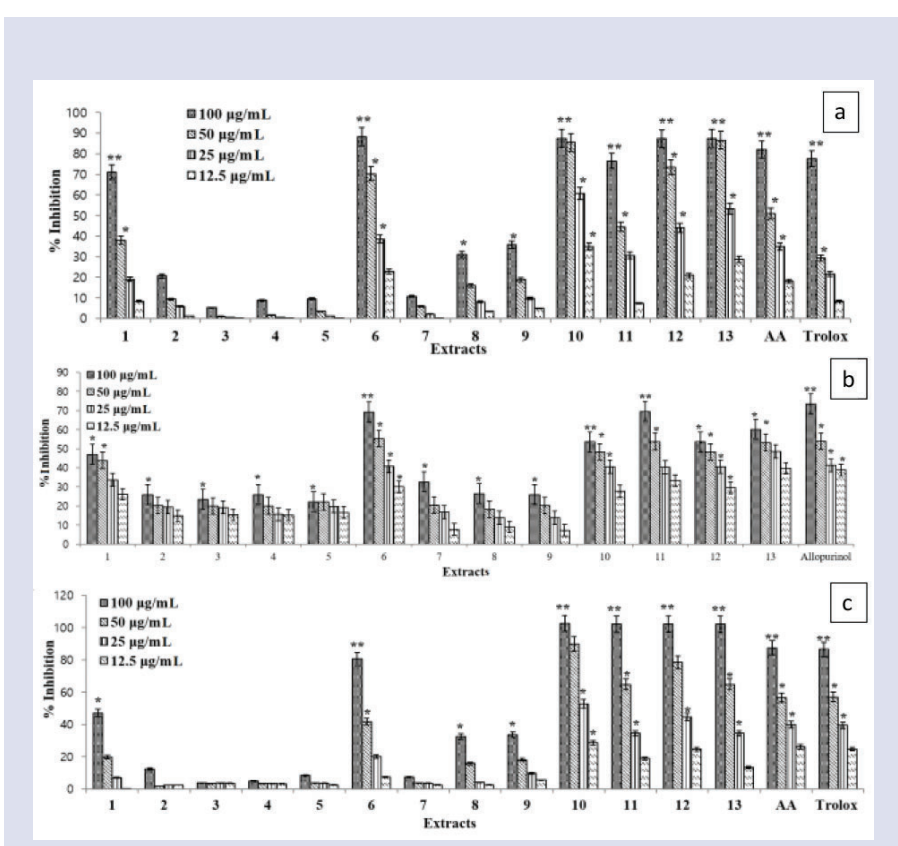

Figure 3: Antioxidant activity of different species of $C$. decapetala. Values are expressed in mean \pm S.D $\left(* *\right.$ p value $\left.<0.01,{ }^{*}<0.05, n=3\right)$.

in C. decapetala and C. bonduc. The highest amount of compound 5 (astragalin) is found in C. sappan while Caesalpinia pulcherrima contains highest amount of compound 7 (quercitrin).

Some of these compounds are identified for the first time in C. decapetala and other species along with their HPLC chromatogram. Therefore, the 
isolated compounds from C. decapetala along with the other species of Caesalpinia were further selected for their antioxidant activity.

\section{Antioxidant capacity}

Active oxygen and free radical role in the progression of certain diseases in human such as ageing of skin and atherosclerosis has been well established. In this study, three free radicals such as DPPH radical, ABTS radical and superoxide anion radical were utilized to check the activities of the extracts and major isolated components from the leaves of C. decapetala. Table 2 and Figure 2 (a) presented the DPPH activity of isolated compounds and extracts of different species. Among the extract of different species, C. pulcherrima collected from China and Pakistan showed the best activity as compared to others in descending order, C.sappan $>$ C. decapetala $>$ C. Bonduc. Among all the isolated compounds, quercitrin exhibited the significant inhibition of DPPH in dose-dependent way. The $\mathrm{IC}_{50}$ value of quercitrin is as follows $48.94 \pm 0.17 \mu \mathrm{M}$. Quercitrin showed the higher DPPH value than trolox but less than AA, positive controls.

In the measurement of superoxide anion radical scavenging activity of isolated compounds, hypoxanthine-xanthine oxidase system as a source of superoxide radical was used. The superoxide anion radical scavenging activity of isolated compounds and extracts are mentioned in Table 2 and Figure 2 (b). According to condition employed, C. Pulcherrima collected from botanical garden in China and Pakistan exhibited the significant antioxidant activity as compared to others followed by, in decreasing order, C.sappan $>$ C. decapetala $>$ C. Bonduc while among the isolated compounds from $C$. Decapetala, quercitrin showed the significant inhibition activity $93.39 \pm 1.86 \mu \mathrm{M}$ in comparison with the other compounds but less activity than standard, allopurinol, $92.54 \pm 0.69 \mu \mathrm{M}$.

ABTS radical scavenging activity of the major isolated compounds and extracts as shown in Table 2 and Figures 2 (c). According to condition employed in the assay, among the extracts of different species of Caesalpinia collected from different areas, samples of C. pulcherrima showed the best activity as compared to others followed by, in decreasing order, C.sappan > C. decapetala $>$ C. Bonduc. Among the isolated compounds, only the quercitrin showed the potent inhibition activity as $60.42 \pm 0.007 \mu \mathrm{M}$. But the $\mathrm{IC}_{50}$ value was less than the standard control, AA and trolox.

\section{a-glucosidase inhibiting capacity}

In the measurement of the a-glucosidase inhibitory activity of isolated compounds, glucosidase enzyme was used. The inhibitory activity of the compounds isolated from $C$. decapetala as mentioned in Table 2 and Figure 3 (a). According to condition employed, compounds 1, 5, 6, and 7 exhibited significant activity against $\alpha$-glucosidase enzyme with $\mathrm{IC}_{50}$ $213.4 \pm 1.0 \mu \mathrm{M}, 311.8 \pm 0.00 \mu \mathrm{M}, 231.6 \pm 8.7 \mu \mathrm{M}$, and $223.0 \pm 0.32 \mu \mathrm{M}$ respectively in comparison with the positive standard acarbose, $\left(\mathrm{IC}_{50}\right.$; $127.9 \pm 2.0 \mu \mathrm{M})$.

\section{PTP1B inhibiting capacity}

In the measurement of the PTP1B inhibitory activity of isolated compounds, PTP1B was used. The inhibitory activity of the compounds isolated from $C$. decapetala is mentioned in Table 2 and Figure 3 (b). According to condition employed, only compound 2 showed the significant inhibitory activity with $\mathrm{IC}_{50}(43.4 \pm 1.7 \mu \mathrm{M})$, while others did not show any activity against this enzyme in comparison with the positive control, an Ursolic acid having $\mathrm{IC}_{50} 0.8 \pm 1.4 \mu \mathrm{M}$.

There are many factors which are responsible for the cause of DM such as oxidative stress and enzyme inhibition. ${ }^{2}$ By finding the natural resources and identification of the responsible compounds, new invention can be made for the treatment of this disease. ${ }^{3}$ Genus Caesalpinia has been used for a very long time for the treatment of diabetes ${ }^{17}$ but it was yet to be identified that which active agents are responsible for the cure of diabetes and by which mechanism the bioactive constituents showed activity against DM.

One of the main reasons of DM is related to the damage of pancreatic $\beta$-cells. ${ }^{18}$ This damaged is stimulated by the presence of excess amount of free radicals which results in excessive oxidative stress. ${ }^{19}$ To determine the antioxidant ability of the isolated compounds from $C$. decapetala along with extract of different species of genus Caesalpinia, we resorted three radical scavenging assay including DPPH assay, ABTS assay, and superoxide radical scavenging assay. Among the isolated compounds, only the quercitrin showed the significant inhibition against DPPH, ABTS assay, and superoxide radical assays. But in the case of extracts of different species of genus Caesalpinia exhibited different pattern against oxidant activity. We observed from our experiments that antioxidant activity against all used assays showed the similar pattern of inhibitory

Table 2: IC $\mathrm{C}_{50}$ values of bioassays of isolated compounds from C. decapetala

\begin{tabular}{cccccc}
\hline \multicolumn{5}{c}{$\mathrm{IC}_{50}(\mathrm{nM})$} \\
\hline Compound name & DPPH assay & ABTS assay & Superoxide assay & a-glucosidase assay & PTP1B assay \\
\hline Apigenin-7- rhamnoside & $>500$ & $>500$ & $>500$ & $213.4 \pm 1.0$ & $\mathrm{Nd}$ \\
4-O-Methyl episappanol & $>500$ & $>500$ & $347.4 \pm 2.1$ & $952.5 \pm 0.7$ & $43.4 \pm 1.7$ \\
Caesalpinol & $>500$ & $>500$ & $357.6 \pm 1.2$ & $685.3 \pm 0.2$ & $\mathrm{Nd}$ \\
Daucosterol & $>500$ & $>500$ & $298.4 \pm 1$ & $758.8 \pm 10.3$ & $\mathrm{Nd}$ \\
Astragalin & $>500$ & $>500$ & $297.1 \pm 0.9$ & $311.8 \pm 0.00$ & $\mathrm{Nd}$ \\
6-hydroxy kaempferol & $>500$ & $>500$ & $288.4 \pm 3$ & $231.6 \pm 8.7$ & $\mathrm{Nd}$ \\
Quercitrin & $60.4 \pm 0.9$ & $87.5 \pm 1.2$ & $64.0 \pm 1.3$ & $223.0 \pm 0.3$ & $\mathrm{Nd}$ \\
Naringin & $>500$ & $>500$ & $296.5 \pm 2$ & $758.8 \pm 10.3$ & $\mathrm{Nd}$ \\
Ascorbic acid & $51.7 \pm 0.1$ & $82.9 \pm 2$ & $\mathrm{Nt}$ & $\mathrm{Nt}$ & $\mathrm{Nt}$ \\
Trolox & $59.4 \pm 0.9$ & $96.2 \pm 1.5$ & $\mathrm{Nt}$ & $\mathrm{Nt}$ & $\mathrm{Nt}$ \\
Allopurinol & $\mathrm{Nt}$ & $\mathrm{Nt}$ & $92.5 \pm 2.3$ & $\mathrm{Nt}$ & $\mathrm{Nt}$ \\
Acarbose & $\mathrm{Nt}$ & $\mathrm{Nt}$ & $\mathrm{Nt}$ & $127.9 \pm 2.0$ & $\mathrm{Nt}$ \\
Ursolic acid & $\mathrm{Nt}$ & $\mathrm{Nt}$ & $\mathrm{Nt}$ & $\mathrm{Nt}$ & $0.8 \pm 1.4$ \\
\hline
\end{tabular}


activity in a dose-dependent manner and a decrease in following order C. Pulcherrima $>$ C.sappan $>$ C. decapetala $>$ C. Bonduc. Quantitative and qualitative analysis showed that quercitrin is present in decreasing order as C. Pulcherrima > C.sappan $>$ C. decapetala $>$ C. Bonduc. The property and popularity of the medicinal plants are due to the presence of their more bioactive compounds. As the results exhibited that quercitrin is a most bioactive component in genus Caesalpinia as an antioxidant. Our findings revealed that antioxidant property of C. Pulcherrima is due to the presence of quercitrin.

In our investigation in searching for the potential glucosidase inhibitor, all the isolated compounds from $C$. decapetala were tested against glucosidase inhibition and flavonoids derivatives showed good results. The flavonoid compounds isolated from $C$. decapetala showed activity at the dose of $250 \mu \mathrm{M}$ in decreasing order: apignin-7-rhmanoside > quercitrin $>6$-hydroxy-kaempferol $>$ astragalin $>$ naringin. Previousstudies on flavonoid potency showed that in the a-glucosidase activity, the structure of flavonoid plays a very important role. ${ }^{20}$ The A, B, and C rings of flavonoids are related to the activity. The linkage of B-ring at position 3 , 2,3-double bond, and hydroxylation at position 5 play a critical role and enhance its activity. Literature related to the $\alpha$-glucosidase activity of flavonoids proves that the inhibitory activity increase with the increase in hydroxyl group on the $\mathrm{B}$ ring. But hydroxylation at position 3 on the $\mathrm{C}$ ring is unfavorable to inhibitory activity. ${ }^{20-23}$ Due to the presence of high amount of quercitrin in Caesalpinia pulcherrima, we can suggest that this species is more valuable against $\alpha$-glucosidase activity for the treatment of DM. In the determination of PTP1B activity of isolated compounds from C. decapetala, the results showed that only compound 2 showed the significant activity in a dose-dependent manner. Therefore, we can suggest that genus Caesalpinia has a potential source of antidiabetic agents which can treat the DM in multiple ways. Future studies may be helpful to explore detailed mechanism of these bioactive constituents in animal models.

\section{CONCLUSION}

The present study reveals that quercitrin is the lead bioactive compound and C. pulcherrima is the most bioactive specie of genus Caesalpinia. In conclusion, the biological activities of the extracts of different species of genus Caesalpinia and their bioactive compounds that we have studied were in the alignment with their ethnopharmacological uses. We have explored the phytochemical composition of $C$. decapetala for the first time and proved its traditional use against diabetes with scientific evidence along with the content determination among different species of genus Caesalpinia belonging to different origins. Consequently, extract of Caesalpinia pulcherrima can be commercialized as a source of antidiabetic agents Furthermore, in-vivo study may help to explore the detailed mechanism about antidiabetic effect of Caesalpinia pulcherrima.

\section{ACKNOWLEDGEMENT}

Nil

\section{CONFLICT OF INTEREST}

Authors have no conflict of interest to report.

\section{ABBREVIATIONS USED}

ANOVA: A one-way analysis of variance; ABTS: 2,2'-azino-bis (3-ethylbenzthiazoline-6-sulfonic acid); BuOH: Butanol; DM: Diabetes mellitus; DPPH: (2,2-diphenyl-1-picrylhydrazyl); HPLC: High Pressure Liquid Chromatography; MeOH: Methanol; NMR: Nuclear Magnetic Resonance; PTP1B: Protein tyrosine phosphatase 1B; ROS: Reactive Oxygen Species; TLC: Thin Layer Chromatography.

\section{REFERENCES}

1. Zhang $P$, Zhang $X$, Brown J, et al. Global healthcare expenditure on diabetes for 2010 and 2030. Diabetes Res. Clin. Pract. 2010;87:293-301.

2. Giacco F, Brownlee M. Oxidative stress and diabetic complications. Circul. Res. 2010;107:1058-1070.

3. Parveen A, Akash MSH, Rehman K, Kyunn WW. Recent Investigations for Discovery of Natural Antioxidants: A Comprehensive Review. Critical Reviews ${ }^{T M}$ in Eukaryotic Gene Expression. 2016;26.

4. Brownlee M. Biochemistry and molecular cell biology of diabetic complications. Nature. 2001;414:813-820.

5. Naquvi KJ, Ahamad J, Mir SR, Ali M, Shuaib M. Review on role of natural î 'Ipha-glucosidase inhibitors for management of diabetes mellitus. International Journal of Biomedical Research. 2011;2:374-380.

6. Delibegovic M, Mody N. Protein tyrosine phosphatase 1B (PTP1B) in obesity and type 2 diabetes. Acta Med Sal. 2009;38:2-7.

7. Parveen A, Akash MSH, Rehman K, Mahmood Q, Qadir MI. Analgesic, antiinflammatory and anti-pyretic activities of Caesalpinia decapetala. Biolmpacts: BI. 2014;4:43

8. Hussain L, Qadir MI. Antihyperglycemic and hypolipidemic potential of Caesalpinia decapetala in alloxan-induced diabetic rabbits. Bangladesh Journal of Pharmacology. 2014;9:529-532

9. Parveen A, Kyunn WW. Antioxidant and Anti-Cholinergic Activities of Phenolic Compounds Isolated From Thymus Linearis Collected from Dir, Pakistan. Vegetos An International Journal of Plant Research. 2016;29:41-46.

10. Chowdhury S, Islam M, Jung $H$, Choi J. In vitro antidiabetic potential of the fruits of Crataegus pinnatifida. Res. Pharm. Sci. 2014;9:11.

11. Zhao H, Bai H, LiW, Li J, Wang Y. Study on chemical constituents of Caesalpinia sappan L. Food and Drug. 2010;12:176-180.

12. Woldemichael GM, Singh MP, Maiese WM, Timmermann BN. Constituents of antibacterial extract of Caesalpinia paraguariensis Burk. Zeitschrift für Naturforschung C. 2003;58:70-75.

13. Mouffok S, Haba H, Lavaud C, Long C, Benkhaled M. Chemical constituents of Centaurea omphalotricha Coss. \& Durieu ex Batt. \& Trab. Records of Natural Products. 2012;6:292

14. Saito S, Silva G, Santos RX, Gosmann G, Pungartnik C, Brendel M. Astragalin from Cassia alata induces DNA adducts in Vitro and repairable DNA damage in the yeast Saccharomyces cerevisiae. Int. J. Mol. Sci. 2012;13:2846-2862.

15. Semwal S, Sharma RK, Bamola A, Pundeer G, Rawat U. Anthraquinone glucosides from aerial parts of Polygonum macrophyllum D. Don. 亚洲传统医药. 2010;5:219-225

16. Lee SJ, Kim J-C, Kim MJ, et al. Transglycosylation of naringin by Bacillus stearothermophilus maltogenic amylase to give glycosylated naringin. J. Agric. Food Chem. 1999;47:3669-3674.

17. Zanin JLB, De Carvalho BA, Salles Martineli $P$, et al. The genus Caesalpinia L.(Caesalpiniaceae): phytochemical and pharmacological characteristics. Molecules. 2012;17:7887-7902.

18. Prentki M, Nolan CJ. Islet $\beta$ cell failure in type 2 diabetes. The Journal of clinical investigation. 2006;116:1802-1812.

19. Asmat U, Abad K, Ismail K. Diabetes mellitus and oxidative stress-a concise review. Saudi Pharmaceutical Journal. 2016;24:547-553.

20. Tadera K, Minami Y, Takamatsu K, Matsuoka T. Inhibition of $\alpha$-glucosidase and $\alpha$-amylase by flavonoids. J. Nutr. Sci. Vitaminol. 2006;52:149-153.

21. Pereira DF, Cazarolli LH, Lavado $C$, et al. Effects of flavonoids on $\alpha$-glucosidase activity: potential targets for glucose homeostasis. Nutrition. 2011;27:1161-1167.

22. Jong-Sang K, Chong-Suk K, Son KH. Inhibition of alpha-glucosidase and amylase by luteolin, a flavonoid. Biosci., Biotechnol., Biochem. 2000;64:2458-2461.

23. Yuan E, Liu B, Wei Q, Yang J, Chen L, Li Q. Structure activity relationships of flavonoids as potent alpha-amylase inhibitors. Nat. Prod. Commun. 2014;9: $1173-1176$ 


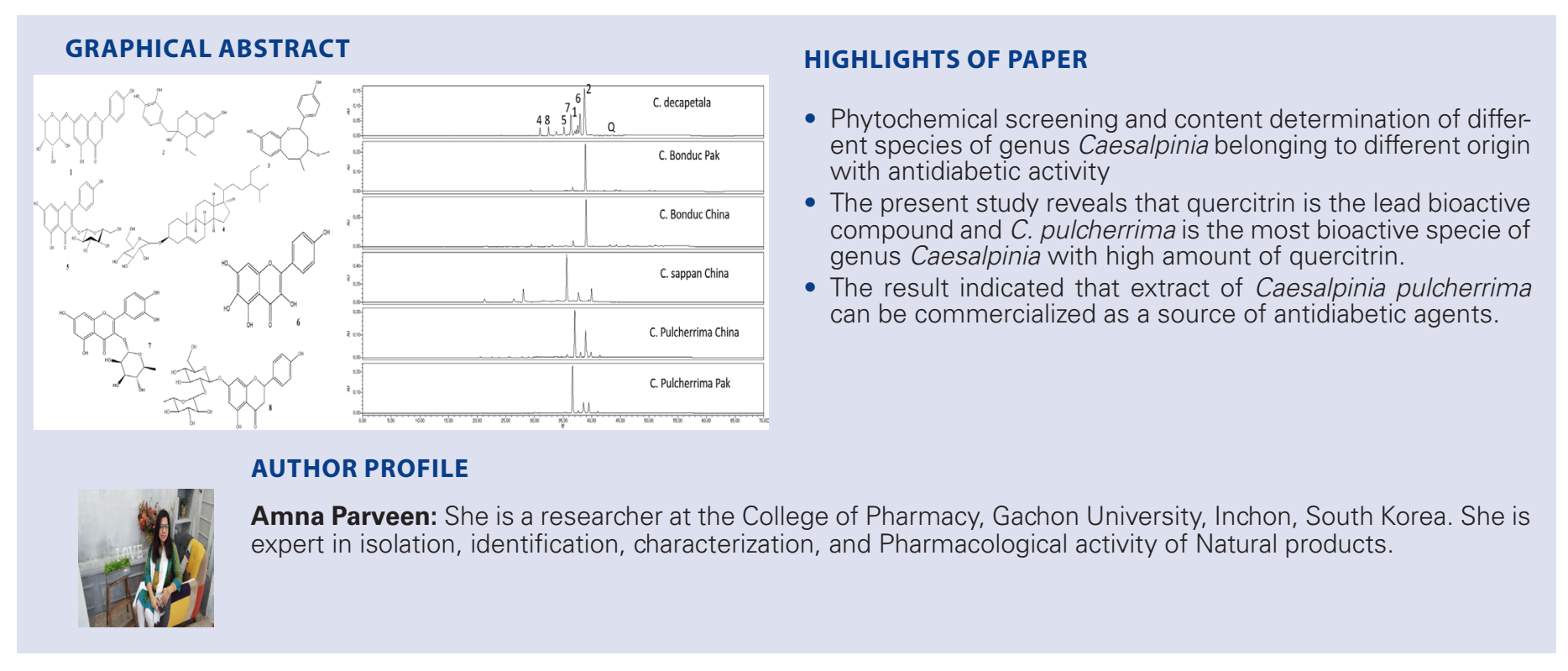

Cite this article : Parveen A, Zahrad, Farooqie MQ, Kyunnb WW, Arshadd M. Phytochemical screening and content determination of different species of genus Caesalpinia belonging to different origin with antidiabetic activity. Pharmacog J. 2017;9(6):743-9. 